\title{
SPECIFIC FEATURES OF STRUCTURES IN THE INNER COMA OF COMET C/2017 T2 (PANSTARRS) AS OBSERVED WITH THE OMT-800 TELESCOPE OF THE ODESSA OBSERVATORY TELESCOPE NETWORK
}

\author{
V.V. Kleshchonok ${ }^{1}$, S.G. Kashuba ${ }^{2}$, S.M. Andrievsky ${ }^{2}$, Yu.M. Gorbanev ${ }^{2}$ \\ ${ }^{1}$ Astronomical Observatory, Taras Shevchenko National University of Kyiv, \\ Kyiv, Ukraine,klev@observ.univ.kiev.ua \\ 2 Astronomical Observatory of Odessa National University, \\ Odessa, Ukraine,vladimir.kashuba@gmail.com, andrievskii@ukr.net,skydust@ukr.net
}

ABSTRACT. Observations of the comet were carried out using the OMT-800 telescope (the primary mirror diameter $\mathrm{D}=80 \mathrm{~cm}$; the focal length $\mathrm{F}=$ $214 \mathrm{~cm}$ ) of the Odessa Observatory telescope network from January to June 2020. Image processing was performed through standard methods using subtraction of dark and flat field frames. The resulting frames were employed to analyse the morphology of the cometary inner coma using digital filters. Isophotes of the coma and images of its structures appearing as fans and jets were obtained. The presence of a strong fan, which distorts the coma's standard appearance and makes it elongated perpendicularly to the Sun-comet line, is observed over the period from January to April. Later on, a weak jet that hardly affects the coma's standard shape appears to replace the fan. The jet reaches its peak intensity near perihelion and then gets fainter rapidly. Such behaviour of the coma structures is indicative of the presence of two active areas on the cometary nucleus surface, for which the matter outflow is governed by the Sun illumination conditions. One of these areas, being more active, is responsible for the appearance of a strong fan. The other area, which is far less active, generates a jet that manifests itself near perihelion. The peak dust production of the comet 120-150 days before perihelion is due to the presence of an active fan in the inner coma.

Keywords: Comets: individual: C/2017 T2.

АНОТАЦІЯ. Особливості структур внутрішньої коми комети $\mathrm{C} / 2017$ T2 (PANSTARRS) за спостереженнями на телескопі ОMT-800 мережі телескопів одеської обсерваторії. Спостереження комети проводились на телескопі ОМТ-800 $(\mathrm{D}=80 \mathrm{~cm}, \mathrm{~F}=214 \mathrm{~cm})$ мережі телескопів одеської обсерваторії протягом січень-червень 2020 p. Обробка зображень проводилася стандартним способом 3 врахуванням темнових кадрів та кадрів плоского поля. Отримані таким чином кадри використовувалися для аналізу морфології внутрішньої коми комети 3 використанням цифрових фільтрів. Були отримані ізофоти коми та зображення структур у вигляді фенів i джетів. Було відмічено існування потужного фену в період січень - квітень, який спотворює стандартний вигляд коми і робить їі витягнутою перпендикулярно напрямку Сонце комета. Пізніше на зміну фену з'являється слабий джет, який майже не впливає на стандартний вигляд коми. Він досягає максимальної інтенсивності близько перигелію, а потім швидко слабішає. Така поведінка структур свідчить про наявність двох активних ділянок на поверхні ядра комети, режим витоку речовини яких регулюється умовами освітленості Сонцем. Одна більш активна ділянка відповідає за появу потужного фену. Друга значно менш активна породжує джет, який проявляєть біля перигелію. Наявністю активного фену пояснюється максимум пилопродуктивності комети за 120-150 днів до перигелію.

Ключові слова: Комети: індивідуальні: С/2017 Т2.

\section{Introduction}

Comet C/2017 T2 (PANSTARRS) was discovered on 2 October 2017 at a distance of 9.2 au from the Sun using a 1.8-metre (60-inch) diameter telescope in Hawaii (http://www.ifa.hawaii.edu/info/pressreleases/PS1/). $\mathrm{C} / 2017 \mathrm{~T} 2 \quad$ (PANSTARRS) is a long-period near-parabolic comet. It passed through perihelion at a heliocentric distance of 1.615 au on 4 May 2020. Most of the comet's observations have been conducted earlier in 2020 when the comet reached its peak brightness; hence, there have been almost no results of studies of this comet published so far. 


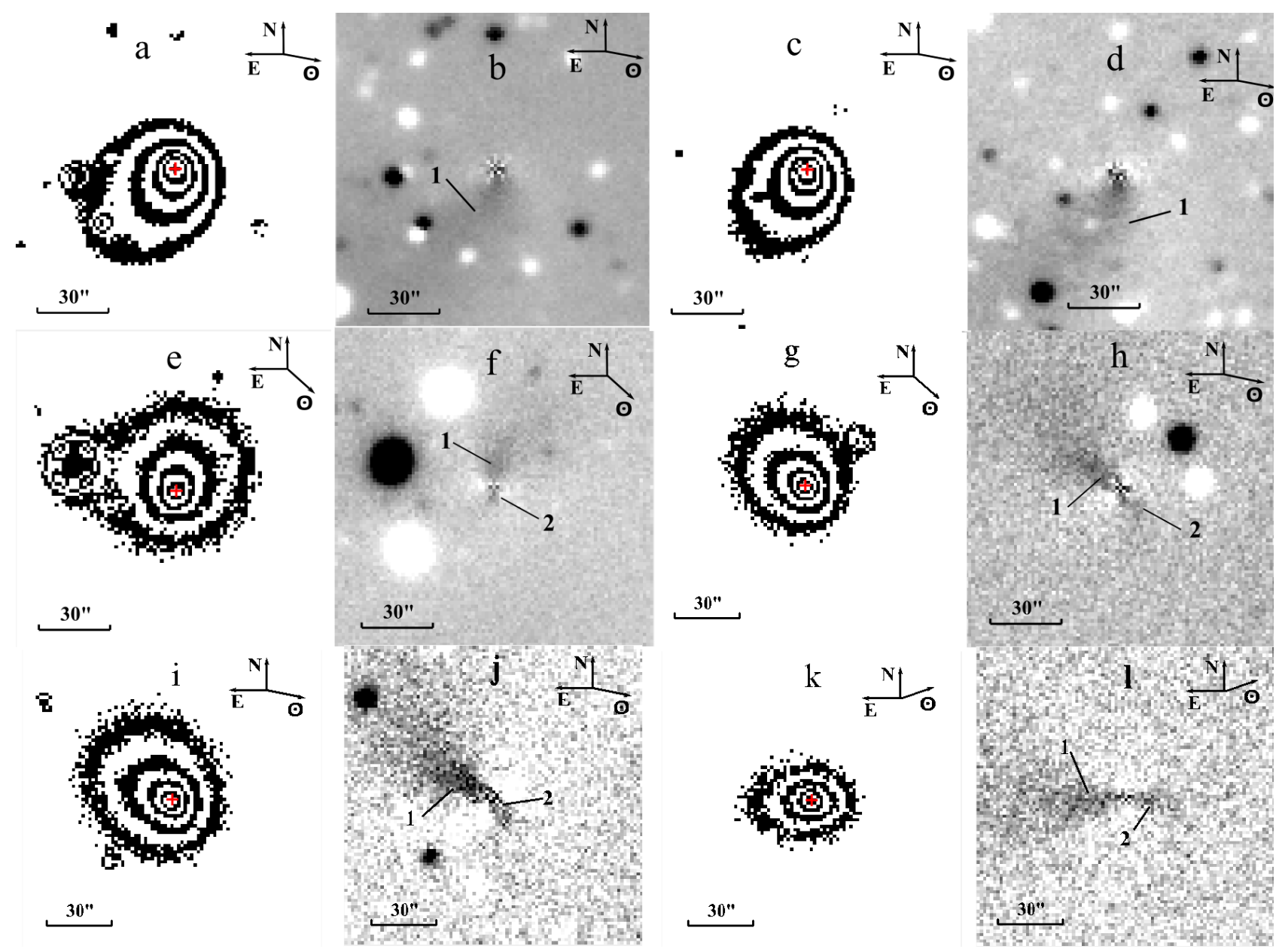

Figure 1: Digitally processed images of comet C/2017 T2 (PANSTARRS) obtained with the OMT-800 telescope. Figures 1a, 1c, 1e, 1g, 1i and 1k illustrate isophote lines superimposed on the processed images. Figures 1b, 1d, $1 \mathrm{f}, 1 \mathrm{~h}, 1 \mathrm{j}$ and $1 \mathrm{l}$ depict the images digitally enhanced using the rotational gradient filter (negative). Figures $1 \mathrm{a}$ and $1 \mathrm{~b}$ present images obtained on 24 January 2020; 1c and 1d - 25 January 2020; 1e and 1f - 23 April 2020 ; $1 \mathrm{~g}$ and $1 \mathrm{~h}-10$ May 2020; $1 \mathrm{i}$ and $1 \mathrm{j}-13$ May 2020; $1 \mathrm{k}$ and $1 \mathrm{l}-08$ June 2020. Arrows indicate the direction to the Sun (8), North $(\mathrm{N})$ or East $(\mathrm{E})$.

$\mathrm{C} / 2017 \mathrm{~T} 2$ is an inactive comet. Even though the comet is dynamically new and it passed fairly close to the Sun, it remains relatively faint. It apparently suggests a small size of the comet nucleus of $10-15 \mathrm{~km}$. According to the CARA (Cometary Archive for Afrho; http://cara.uai.it) data, comet C/2017 T2 exhibits unusual behaviour with respect to dust activity. The comet's dust production $(A f \rho)$ reached its maximum 150-120 days before perihelion (in December 2019 January 2020). Moreover, there was a secondary peak 50 days before perihelion (in March 2020). After the perihelion passage, a noticeable and regular decrease in dust production has been observed. The present paper explains such behaviour of the comet through analysis of morphological changes in the inner coma.

\section{Observations and analysis}

Observations of the comet were carried out using the OMT-800 telescope (the primary mirror diameter $\mathrm{D}=$ $80 \mathrm{~cm}$; the focal length $\mathrm{F}=214 \mathrm{~cm}$ ) at Mayaki observing station of Astronomical Observatory of Odesa National University (Andrievsky et al., 2013). The observational data are listed in Table 1, which presents the date of observation, the heliocentric distance $-r$, the geocentric distance $-\delta$, the phase angle $-\alpha$, respective magnitudes of the comet, as well as exposures used to capture the comet in the frame and number of frames with a given exposure.

Preliminary processing of the obtained frames was performed using standard methods. A master dark frame was created from a set of 9-15 dark frames with an exposure equal to that for light frames using median 
Table 1: Log of the observations of comet $\mathrm{C} / 2017 \mathrm{~T} 2$ (PANSTARRS)

\begin{tabular}{|c|c|c|c|c|c|c|c|}
\hline$\#$ & Date & $r(\mathrm{au})$ & $\delta(\mathrm{au})$ & $\alpha(\mathrm{deg})$ & $\mathrm{mag}^{*}$ & $\mathrm{~T}_{\exp }(\mathrm{sec})$ & $\mathrm{N}$ \\
\hline 1 & 24 Jan 2020 & 2.096 & 1.593 & 26.7 & 9.6 & 16,60 & 12,45 \\
2 & 25 Jan 2020 & 2.087 & 1.599 & 27.0 & 9.4 & 60 & 48 \\
3 & 23 Apr 2020 & 1.622 & 1.723 & 34.8 & 9.0 & 16 & 40 \\
4 & 10 May 2020 & 1.617 & 1.680 & 35.6 & 8.6 & 16 & 103 \\
5 & 13 May 2020 & 1.619 & 1.674 & 35.7 & 8.4 & 16 & 253 \\
6 & 08 Jun 2020 & 1.682 & 1.681 & 35.2 & 9.0 & 16 & 32 \\
\hline
\end{tabular}

*Adopted from https://cobs.si

Table 2: Structures in the inner coma of comet C/2017 T2 (PANSTARRS)

\begin{tabular}{|c|c|c|c|c|c|c|c|}
\hline$\#$ & Date & \multicolumn{3}{|c|}{ Structure 1 } & \multicolumn{3}{c|}{ Structure 2} \\
\hline & & $\varphi(\mathrm{deg})$ & $\omega(\mathrm{deg})$ & $\rho(104 \mathrm{~km})$ & $\varphi(\mathrm{deg})$ & $\omega(\mathrm{deg})$ & $\rho(104 \mathrm{~km})$ \\
\hline 1 & 24 Jan 2020 & 170 & 77 & 3.9 & - & - & - \\
2 & 25 Jan 2020 & 169 & 72 & 3.2 & - & - & - \\
3 & 23 Apr 2020 & 2 & 45 & 2.3 & 176 & 32 & 0.7 \\
4 & 10 May 2020 & 53 & 33 & 5.8 & 209 & 27 & 1.3 \\
5 & 13 May 2020 & 65 & 30 & 6.0 & 214 & 33 & 1.5 \\
6 & 08 Jun 2020 & 100 & 34 & 5.2 & 237 & 41 & 1.3 \\
\hline
\end{tabular}

filtering technique. A master flat frame was created in a similar way. The master dark was subtracted from each light frame with subsequent division of the resulting frame by the master flat. All images were digitally processed to amplify and extract specific structural features of the inner coma. The coma isophotes were plotted for different observation dates. The isophotes were drawn so that their intensity was decreasing by a factor of $\sqrt{2}$ when shifting towards the coma edges. Images of the comet were also digitally enhanced employing the rotational gradient filter (Larson \& Sekanina 1984). The results are shown in Figure 1.

The isophotes indicate a significant asymmetry of the inner coma. In January, the coma is elongated southwards and almost perpendicular to the Sun's direction. In April, the coma is elongated southward, which is also greatly different from usual anti-solar direction. At later observation dates, the coma is elongated in anti-solar direction due to the contribution of the cometary tail to the total brightness of the coma. Fans and jets can be seen in the images processed using the rotational gradient filter. Such structures were also highlighted in the study by Manzini et al. (2020). A wide and contrast fan-shaped structure can be seen in the images taken in January. Two oppositely directed jets with substantially different intensities and extensions can be observed in the images obtained in April. Observations in May and June 2020 show two structures: a flat (low contrast) structure (b) is a low intensity jet; a more prominent structure (a) in anti-solar direction is the cometary tail that has not manifested itself in earlier observations. Parameters of the jets are given in Table 2, which presents the observation date, the position angle $-\varphi$, the cone angle (width) $-\omega$ and the extension of the jet $-\rho$.

\section{Interpretation and discussion of the results}

The appearance of comet C/2017 T2 depends significantly on the presence and activity of jet structures. A strong fan-shaped structure can be observed in images taken in January (Figure $1 \mathrm{~b}$ and $1 \mathrm{~d}$ ); this fan forms the comet into a peculiar shape, which is elongated almost perpendicularly to the Sun's direction (Figure $1 \mathrm{a}$ and 1c). When approaching the perihelion, the fan gets fainter, and the second very weak jet appears (Figure 1f), which results in decreasing compression ratio of the coma (Figure 1e). Observations in May and June show a weak jet (jet 2 in Figure $1 \mathrm{~h}, 1 \mathrm{j}$ and $1 \mathrm{l}$ ) that has reached its peak activity shortly after passing the perihelion and then became weaker. Structural feature 1 in the same images practically coincides with the anti-solar direction and has a noticeable extension, which suggests that in this case we observe the cometary tail. Such behaviour of structures in the inner coma, as well as changes in its shape and dust production rate around perihelion, is very similar to the behaviour of well-studied comet $2 \mathrm{P} /$ Encke (Sekanina, 1979; Rosenbush et al., 2020). There are two active areas in the nucleus of comet $2 \mathrm{P} /$ Encke that have been existing for a sufficiently long period of time. Due to the location of these active sites in the nucleus of comet $2 \mathrm{P} /$ Encke, as well as orientation of the rotation axis of the cometary nucleus, it turns out that one active area is illuminated for the greater part of the comet's rotation period, except for a very short period of time near perihelion. However, depending on the mutual position of the comet and Earth, this active area can produce either a wide fan-shaped structure or narrower jets. When such a wide fan is observed in the cometary coma, the coma is elongated in the direction 
not coinciding with the anti-solar direction. During this time, the yield by this active area contributes markedly to the emission of matter by the remaining part of the nucleus. The presence of such an active area in the nucleus of comet $2 \mathrm{P} /$ Encke also results in a shift in the peak brightness with respect to the time of perihelion passage. The second active area in comet $2 \mathrm{P} /$ Encke is far less productive, being illuminated by the Sun just for a short period of time when the comet is near perihelion. Similar behaviour of these two comets allows us to suggest a similar explanation of such behaviour, in particular, by the presence of two active areas with different production rates in the cometary nucleus. Engaging additional observations of comet $\mathrm{C} / 2017 \mathrm{~T} 2$ will enable us to determine the orientation of its rotation axis and location of active areas on the nucleus of this comet.

\section{Conclusions}

Peculiarities of changes in the shape of coma and behaviour of its specific structural features are indicative of the presence of two active areas in the nucleus of comet $\mathrm{C} / 2017 \mathrm{~T} 2$. The presence of an active highproductive area in the nucleus of comet C/2017 T2 enables us to explain specific features of dust activity of the comet, in particular, reaching the maximum dust production 120-150 days before the perihelion passage.
Acknowledgements. The research of V. Kleshchonok was supported in part by the $16 \mathrm{BF} 023-02$ project of the Taras Shevchenko National University of Kyiv.

\section{References}

Andrievsky S.M. et al.: 2013, Odessa Astron. Publ., 26, 6 .

Larson S.M. et al: 1984, A.J., 89, 571.

Manzini F. et al.: 2020, The Astronomer's Telegram., No 13698.

Rosenbush V. et al.: 2020, Icarus., 348, id. 113767.

Sekanina Z.: 1979, Icarus., 37, 420. 